Sonja Jovanović

P. 1-7

University of Niš

ORIGINAL SCIENTIFIC ARTICLE

Faculty of Economics

Received: March, 30, 2019

Accepted: June, 15, 2019

\title{
GREEN HOTELS AS A NEW TREND IN THE FUNCTION OF SUSTAINABLE DEVELOPMENT AND COMPETITIVENESS IMPROVEMENT ${ }^{2}$
}

\begin{abstract}
The competitiveness of the hotel industry is a vital component for ensuring the sustainable development of tourism, since hotel industry is one of the largest segments of the tourism industry. One of the important prerequisites for achieving competitiveness in the tourism market is business based on the principles of sustainable development. The incorporation of the sustainability principle into all segments of tourism supply and demand becomes inevitable and increasingly acceptable. The subject of research in this paper is an analysis of the various practices that hotels are introducing into their business to meet the demands of tourists who are environmentally aware and to operate in accordance with the concept of sustainable development. Therefore, the aim of the research is to present the green construction and green business of the hotels as a challenge for the hotel industry in contemporary business conditions.
\end{abstract}

Key words: green hotels, competitiveness, sustainable development, standards.

JEL classification: Z320, Z310

\section{ЗЕЛЕНИ ХОТЕЛИ КАО НОВИ ТРЕНД У ФУНКЦИЈИ ОДРЖИВОГ РАЗВОЈА И УНАПРЕЪЕЊА КОНКУРЕНТНОСТИ}

\begin{abstract}
Апстракт
Конкурентност хотелске индустрије је витална компонента за обезбеђење одрживог развоја туризма, будући да је хотелијерство један од највећих сегмената туристичке индустрије. Једна од важних претпоставки за достизање конкурентности на туристичком тржишту јесте и пословање засновано на принципима одржсивог развоја. Уграђивање принщипа одрживости у све сегменте туристичке понуде и тражюе постаје неизбежно и све више прихватьиво. Предмет истражсиваьа у овом раду јесте анализа различитих пракси које хотели уводе у своје пословање како би изашли у сусрет тражюи туриста који су еколошки свесни и како би пословали у складу са конщептом одрживог развоја. Отуда је ициь истраживања да се прикажу зелена градња и зелено пословање хотела као изазови за хотелску индустрију у савременим условима пословаьа.
\end{abstract}

Кључне речи: зелени хотели, конкурентност, одрживи развоја, стандарди.

\footnotetext{
${ }^{1}$ sonja.jovanovic@eknfak.ni.ac.rs

${ }^{2}$ The paper is a result of research within the project 179066, funded by the Ministry of Education, Science and Technological Development of the Republic of Serbia
} 


\section{Introduction}

The concept of sustainable development is a modern approach when creating policies and strategies of future development in all aspects of economic and social life. The incorporation of the sustainability principle into all segments of tourism supply and demand becomes inevitable and increasingly acceptable. "Nowadays, environmental practices are already part of our daily lives and are changing the way we travel. In this framework, new trends are appearing within the tourism/travel industry and leisure activity all over the world. Over the last decades, the demand of business sustainability made by customers has encouraged the rise of numerous eco-friendly practices in the tourist industry." (Leal Londoño, Hernandez-Maskivker, 2016).

The hotel industry represents a segment of the tourist offer that creates a great negative pressure on the environment. Because of that „it is imperative that the management of hotels take action to mitigate their impact on the environment." (Mbasera, Du Plessis, Saayman, \& Kruger, 2016) There are different ways that business of hotel companies become environmentally friendly or that hotels carry the title of green or sustainable. „Initially green practices of operators are in the area of energy, waste and water. Later the green operators expand their green initiatives in other area such as indoor environmental quality, green materials and resources, sustainable site planning and management, community involvement, biodiversity conservation, human resources development, green transportation, noise control and toxic waste management." (Yusof, Jamaludin, 2014, p.502)

The subject of research in this paper is an analysis of the various practices that hotels are introducing into their business to meet the demands of tourists who are environmentally aware and to operate in accordance with the concept of sustainable development. One of the important prerequisites for achieving competitiveness in the tourism market is business based on the principles of sustainable development. Therefore, the aim of the research is to present the green construction and green business of the hotel as a challenge for the hotel industry in moderncontemporary business conditions.

\section{Factors for improving competitiveness in the hospitality industry in contemporary business conditions}

The competitiveness of the hotel industry is a vital component for ensuring the sustainable development of tourism, since hotel industry is one of the largest segments of the tourism industry. „Each hotel, regardless of its classification, may contribute to the overall performance of the local and national hospitality and tourism industry." (Lacap, 2014, p. 116) Therefore, consideration for factors that can contribute to improving the competitiveness of the hotel industry is reflected in the provision of a higher level of competitiveness of the destination and the overall tourism industry.

Some of the most important factors contributing to the improvement of the competitiveness of the hotel industry are: human resources, information technology, education. Some authors point out that both innovation and costs are key factors in the competitiveness of the hotel industry. (Țuclea, Pădurean, 2008) 
Some authors lists some of the most important factors that will affect competitiveness in hotel industry in contemporary conditions (Črnjar, Vrtodušić-Hrgović, 2013, p. 68):

- the ability of business entities to interact in managing shared resources;

- technology and information technology;

- $\quad$ the ability to transform a company into an organization that is learning and its involvement in a knowledge-based economy;

- the quality of human resources that represent the center of activity in the hotel industry from the creation of products and services to their provision;

- knowledge management and human resources development to improve quality in all segments;

- quality management and continuous improvement of production of products, services, processes.

Other authors point out that marketing and human capital, both in the case of a destination, and in the case of the hotel industry, are key to improving competitiveness. It is especially emphasized that the important factors for the hotel industry are the factors and level of education and the provision of training and training for employees. (Tsai, Song, Wong, 2009)

It can be said that stronger competition stimulates innovation and improves business performance. Hotels confronted with strong competition are innovating products, improving the quality of service, introducing modern technology into their business, approaching modern trends in hotel design, specializing in a particular type of hotel, orienting towards the concept of green business.

In the continuation of this paper accent will be on green business as one of the most important factors that can contribute to improving the competitiveness of hotel companies.

\section{Characteristics and practice of green hotels}

The demand for clean areas, nature, intact areas, is growing. The interest in sustainable development within the hotel industry is becoming more pronounced. More than a hundred hotels in Hungary have received the title green hotel in the last twenty years. (Attila, 2016, p. 93) By definition Green Hotel Association (Green Hotels Association, 2019), green hotels are ecologically oriented facilities that save water, energy, reduce solid waste in their business and thus save money and contribute to protecting and preserving the entire Planet. Through this definition, responsibility for the environment, as well as the local community and the wider, of the entire Planet, is emphasized.

The construction and operation of hotel companies have a significant negative impact on the environment. Hotels are large consumers of energy, water, chemicals for cleaning and maintenance, generators of wastewater. Therefore, the orientation towards green construction and green business provides a friendly attitude towards the environment, approaching the objectives of the sustainable development concept, meeting the demands of an increasing number of tourists who have developed environmental awareness and appreciate this kind of business. Green design and construction of the 
hotel allows not only environmentally responsible behavior, but also luxury environment and economic cost-effectiveness. (Ahn, Pearce, 2013)

„More and more modern tourists are ready to pay the price addition in order to stay in a hotel that does not harm the environment.“" (Bašić, 2015, p. 409) Access to green business allows not only cost savings and improvement of business performance, but also recognizability in the market that more and more tourists demand. Adapting hotel business to green practice, enables its differentiation in a highly competitive market and separation from other hotel offers, thus providing a competitive advantage. „The green attributes of a hotel that influence the creation of their green image are a powerful means of attracting new guests, their satisfaction and loyalty in a competitive environment." (Sekulić, Maksimović, 2013, p. 259)

Business in green hotels involves the automatic shutdown of electronic devices after leaving the room, time limited water flow, recycling of waste. "Green hotels are more energy efficient, recyclable, use renewable energy sources, are less harmful to the environment and are suitable for health tourism, so, besides reducing operating costs, they can operate all year round and increase competitiveness.“ (Bašić, 2015, p. 414)

Among the countries in the region, Croatia and Slovenia stand out from the most green hotels. There are several hotels in Croatia that operate according to the principles of green business. Among these hotels ,is Hotel Split, a certified facility of energy class A that has its own solar power plant, rains rainwater, offers food from domestic production and controlled origin, uses biodegradable cleaning products, lighting designed in LED technology and many other elements of green tourism." (Bašić, 2015, p. 414)

In order for the hotel to be recognized as green, it needs to fulfill certain standards that enable it to obtain the certificate. The world's best-known green certificates are: EarthCheck (won by hotels leading environmental awareness), Green Globe (based on Agenda 21 and sustainable development principles from the 1992 Rio Summit), the Sustainable Tourism Eco-Certification Program. The Energy Star certification is provided by hotels that support energy efficiency, Green Key - hotels that respect ecostandards in business, Green Seal - hotels that save water, energy, recycle, Leadership in Energy and Environmental Design (LEED) - a certificate awarded to hotels that have built green building rules during construction, the Green Tourism Business Scheme (GTBS) - an affiliate scheme for the United Kingdom. In Serbia, Radisson Blu Old Mill, part of the Carlson Rezidor Group, and In Hotel in Belgrade have the Green Key certification since 2015.

Table 1 shows ten hotels in te world that are rated as the best green hotels according to HotesCombined criteria.

\section{Table 1: Top seven green hotels according to HotelsCombined}

\begin{tabular}{|l|l|}
\hline \multicolumn{1}{|c|}{ Hotel } & \multicolumn{1}{c|}{ Examples of green practice } \\
\hline Hi Hotel, Nice, France & $\begin{array}{l}\text { This hotel has received Green Globe certification for using recycled } \\
\text { paper, organic paint, eco-friendly cleaning products and organic } \\
\text { food. }\end{array}$ \\
\hline $\begin{array}{l}\text { Hix Island House, Isla de Vieques, } \\
\text { Puerto Rico }\end{array}$ & $\begin{array}{l}\text { With a focus on nature, the Hix Island House runs on batteries } \\
\text { charged by solar power. It also recycles rainwater, was designed } \\
\text { to catch cooling winds and returns grey water to the environment. }\end{array}$ \\
\hline
\end{tabular}




\begin{tabular}{|c|c|}
\hline $\begin{array}{l}\text { Garonga Safari Camp, Phalaborwa, } \\
\text { Africa }\end{array}$ & $\begin{array}{l}\text { This hotel offer employment opportunities for locals, with potential } \\
\text { for career development, while food and goods are sourced locally } \\
\text { where possible. Additionally, guests are invited to offset their } \\
\text { carbon footprint by assisting with the planting and growing of } \\
\text { Spesbok Trees in the Eastern Cape. }\end{array}$ \\
\hline $\begin{array}{l}\text { Lefay Resort \& SPA Lago di Garda, } \\
\text { Gargnano, Italy }\end{array}$ & $\begin{array}{l}\text { The interior design makes use of local materials, while the design of } \\
\text { the hotel was fashioned in respect to the surrounding landscape and } \\
\text { environment. Rainwater is collected, and the hotel has a sustainable } \\
\text { approach to waste management. }\end{array}$ \\
\hline $\begin{array}{l}\text { Thala Beach Lodge, Port Douglas, } \\
\text { Australia, Port Douglas, Australia }\end{array}$ & $\begin{array}{l}\text { This resort has been awarded with one of the highest eco-tourism } \\
\text { accreditations, Eco certified-Advanced Tourism. }\end{array}$ \\
\hline $\begin{array}{l}\text { Park Hyatt } \\
\text { Hadahaa, Maldives }\end{array}$ & $\begin{array}{l}\text { Various parts of the hotel arebuilt over the water in the Indian Ocean } \\
\text { in order to minimize interference with the natural environment. } \\
\text { Park Hyatt Maldives Hadahaa has been the recipient of a silver } \\
\text { EarthCheck certificate. }\end{array}$ \\
\hline $\begin{array}{l}\text { The Park Hyderabad, Hyderabad, } \\
\text { India }\end{array}$ & $\begin{array}{l}\text { Park Hyderabad's stunning exterior maximizes natural light, } \\
\text { reducing the need for electricity. Green transportation, bikes and } \\
\text { electric cars is encouraged. The hotel fuses local culture with } \\
\text { exceptional design and has achieved Leed Gold certification. }\end{array}$ \\
\hline $\begin{array}{l}\text { Spice Island Beach Resort, St. } \\
\text { George's, Grenada }\end{array}$ & $\begin{array}{l}\text { The resort uses solar heating, desalination plants and all forms } \\
\text { of energy conservation. There is a focus on maximizing the } \\
\text { preservation of the island via community clean-ups, replanting and } \\
\text { non-chlorinated pools. Smoking of any kind (even e-cigarettes) is } \\
\text { forbidden in all areas of the resort which places an emphasis on } \\
\text { body and soul renewal. }\end{array}$ \\
\hline Alila Villas Soori, Bali, Indonesia & $\begin{array}{l}\text { The resort is completely water efficient with rainwater optimized } \\
\text { to meet all of their water needs. More than half of all ingredients, } \\
\text { goods and services are purchased from the local area. Locally } \\
\text { sourced materials such as sand stone and natural stones were used in } \\
\text { building the resort, which incorporates a combination of indigenous } \\
\text { volcanic rock and abundant plants to organically cool the villas. }\end{array}$ \\
\hline $\begin{array}{l}\text { Six Senses Con Dao, Con Dao, } \\
\text { Vietnam }\end{array}$ & $\begin{array}{l}\text { Six Senses Con Dao has been recognised as one of the world's } \\
\text { top eco lodges by National Geographic Traveler. Built using } \\
\text { sustainable building materials, the structure of the resort is designed } \\
\text { to maximize air flow to reduce the need for air conditioning. }\end{array}$ \\
\hline
\end{tabular}

Source: HotelsCombined, https://blog.hotelscombined.com/travelling-green-the-worldstop-eco-friendly-hotels/

Green building orientation, which includes the use of natural materials, the use of renewable energy sources, as well as various forms of water and material recycling, are some of the most common practices of green hotels. Taking care of the employment of people from the local community, as well as encouraging agricultural production through the use of local food in the offer of these hotels, represent a sustainable practice and respect for the principles of sustainable development.

\section{Conclusion}

One of the important prerequisites for achieving competitiveness in the tourism market is business based on the principles of sustainable development. The incorporation of the sustainability principle into all segments of tourism supply and demand becomes inevitable and increasingly acceptable. 
The interest in sustainable development within the hotel industry is becoming more pronounced. Green business as one of the most important factors that can contribute to improving the competitiveness of hotel companies. Hotels are large consumers of energy, water, chemicals for cleaning and maintenance, generators of wastewater. Therefore, the orientation towards green construction and green business provides a friendly attitude towards the environment, approaching the objectives of the sustainable development concept, meeting the demands of an increasing number of tourists who have developed environmental awareness and appreciate this kind of business.

Green building orientation, which includes the use of natural materials, the use of renewable energy sources, as well as various forms of water and material recycling, are some of the most common practices of green hotels. Taking care of the employment of people from the local community, as well as encouraging agricultural production through the use of local food in the offer of these hotels, represent a sustainable practice and respect for the principles of sustainable development.

\section{References}

Ahn, Y. H., Pearce, A. R. (2013) Green Luxury: a case study of two green hotels, Journal of Green Building, Vol. 8, No. 1.

Attila, A. T. (2016) The impact of the hotel industry on the competitiveness of tourism destinations in Hungary, Journal of Competitiveness, Vol. 8, No. 4, str. 93.

Bašić, I. (2015) Novi trendovi u funkciji povećanja konkurentnosti hrvatskog turizma u 21. stoljeću, Zbornik radova „Prostorno planiranje kao čimbenik razvoja u županijama“, Rijeka: Javna ustanova Zavod za prostorno uređenje Primorsko-goranske županije, str. 409.

Črnjar, K., Vrtodušić-Hrgović, A. M. (2013) Znanje i kvaliteta - uvjet konkurentnosti hotelijerstva Hrvatske, Poslovna izvrsnost, Vol. 7, No. 2, str. 68.

Green Hotels Association (2019) http://greenhotels.com/index.php (17.04.2019.)

Han, H., Hsu, L. T. J., Lee, J. S., Sheu, C. (2011) Are lodging customers ready to go green? An examination of attitudes, demographics, and eco-friendly intentions, International Journal of Hospitality Management, Vol. 30, No. 2, str. 350.

HotelsCombined (2019) https://blog.hotelscombined.com/travelling-green-theworlds-top-eco-friendly-hotels/, (25.03.2019.)

Lacap, J. P. G. (2014) Competitiveness and sustainability of the hotel industry: the case of hotels in Pampanga, Business Management and Strategy, Vol. 5, No. 1, str. 116.

M. P. Leal Londoño \& G. Hernandez-Maskivker, Green practices in hotels: the case of the GreenLeaders Program from TripAdvisor, Proceedings of the 7 International Conference thon Sustainable Tourism (ST 2016), https://www.witpress.com/Secure/ elibrary/papers/ST16/ST16001FU1.pdf

Mbasera, M., Du Plessis, E., Saayman, M. \& Kruger, M. 2016, 'Environmentallyfriendly practices in hotels', Acta Commercii 16(1), a362. http://dx.doi.org/10.4102/ ac.v16i1.362, (25.03.2019.) 
Sekulić, D., Maksimović, N. (2013) Zeleni hoteli: značaj „zelenih” atributa za potrošače u hotelijerstvu, Ecologica, br. 70, str. 259.

Tsai, H., Song, H., Wong, K. K. F. (2009) Tourism and hotel competitiveness research, Journal of Travel \& Tourism Marketing, Vol. 26, No. 5-6.

Ţuclea, C. E., Pădurean, A. M. (2008) Competitiveness in hospitality industry: Romanian style, Management and Marketing Journal, Vol. 6, No. 1.

Zeenat Begam Yusof*, Mariam Jamaludin (2014) Barriers of Malaysian Green Hotels and Resorts, Procedia - Social and Behavioral Sciences 153 ( 2014 ) 501 - 509, p. 502 